\title{
KIRJOITUS
}

TIINA LAINE

\section{Diakonia kirkon päättäjän korkona}

Diakoniatyöntekijöiden Liiton toiminnanjohtaja haastettiin pohtimaan: Miten hyvin kirkon päättäjät tuntevat diakoniaa?

Kirkkovaltuutettuna ja entisenä diakoniatyöntekijänä minulla on vuosikymmenten kokemus diakoniasta. Viimeiset 11 vuotta olen vaikuttanut diakonian tekemisen edellytyksiin Diakoniatyöntekijöiden Liitosta käsin. Historiastani johtuen tunnen diakoniatyön ja diakoniatyöntekijöiden mielenmaisemia, kuten muutama muukin kirkon luottamushenkilöistä, mutta useimmilla ei juuri kosketuspintaa ole diakoniatyöhön.

Diakonia muistetaan jokaisessa seurakuntastrategiassa, juhlapuheessa ja diakoniatyöllä vakuutellaan kirkon merkitystä yhteiskunnassa. Diakonia on osa kirkon ikivanhaa traditiota, joka tulee välillä ylenkatsotuksi "vain kirkon sosiaalityönä". Diakonian asiantuntijat jätetään vallan kamareiden ulkopuolelle. Ohitetuksi tuleminen jättää pysyvän jäljen. Muistan nuorena seurakuntaan tulleena diakoniatyöntekijänä, kun Keravan seurakunnassa kirkon ovensuulla seisoivat nuorisotyöntekijät, diakoniatyöntekijät, lapsityönohjaaja ja papisto vastaanottamassa piispaa piispantarkastukseen. Piispa Huovinen käveli koko muun letkan ohi ja kätteli papiston.

2000 luvulle; Diakoniatyöntekijöiden Liiton Helsingin osasto järjesti kapitulin kanssa yhteistyössä seminaaripäivän, jonka keskeinen teema oli tasa-arvo kirkossa ja diakoniatyöntekijöiden työn merkitys. Piispa oli ilmoittanut olevansa päivässä mukana, paikalla oli runsaasti diakoniatyöntekijöitä, dekaani sekä luennoitsijoita. Puhujat olivat valmistautuneet puheenvuoroihinsa, uusia näkökulmia nostaen. Piispa käväisi kahvilla, kehui diakoniatyöntekijät ja otettiin selfie. Kuva oli kiva somessa. Olisi ollut hieno mahdollisuus pysähtyä diakoniatyöntekijöiden kysymysten äärelle. 
Piispoille tieto diakonian arjesta ei synny luontaisesti, ilman, että he haluavat kuunnella ja oppia diakoniatyöntekijöiltä. Nuoremmalla piispakunnalla ei juuri ole työkokemusta eikä koulutusta diakonian kysymyksistä, he kuitenkin ovat päätöksiä valmistelevissa työryhmissä, joten kapitulien ja kirkkohallituksen rooli tiedontuottajana heille korostuu. Diakonian asiantuntija on palkattuna Oulun, Mikkelin, Kuopion ja Lapuan, Tampereen sekä Porvoon kapituleissa, osaamisvajetta diakoniasta on Turun ja Helsingin kapituleissa. Nyt Kirkon työmarkkinalaitos on ilmaissut, että se vähentää resursseja työelämä 2030 hankkeelta, kapitulien rooli asiassa korostuu. Jos diakonian ääni ei siellä kuulu, niin piispojen käsitys kirkosta kapeutuu.

\section{Kaiken takana väärinkäsitys?}

Herätysliikkeiden traditioissa painottuvat uskon kysymykset, evankelioiminen ja lähetystyö. Herätysliikkeille ominaista on myös merkittävä panostus nuorisotyöhön. Luottamushenkilön herätysliiketausta näyttäisi vaikuttavan käsitykseen diakonian merkitykseen seurakunnassa.

Onko millään kirkon herätysliikkeellä diakoniapainotusta tai diakonisia toimintamuotoja? Herätysliikkeissä näyttäisi diakonia olevan lähinnä ulkomaille suuntautuvaa avustustoimintaa ja lähetystyön ohessa tapahtuvaa auttamistyötä. Tässä eri järjestöt tekevät mitenkään väheksymättä tärkeää ja arvokasta työtä. Kaikki ihmiset eivät käyttäydy ja ajattele samalla tavalla herätysliikkeissäkään. Ei siis voida suoraviivaisesti vetää yhtäläisyysmerkkejä diakoniakäsityksen ja herätysliiketaustan välille. Arkikokemus on kuitenkin osoittanut, että yleiskirkolliseksi itsensä määrittävät luottamushenkilöt ovat usein avoimempia diakonialle, eivätkä he näe diakoniaa uhkana kirkon julistustyölle. Tässä olisi aihe, joka kaipaa selvästi tutkimusta.

Oma lukunsa on jonkinlainen jännitteisyys evankelioivan lähetyksen ja diakonian välillä. Olen joskus kuullut hengellisiä puheita, joissa merkillisellä tavalla diakonia ja evankeliointi on asetettu vastapuoliksi. Voiko diakoniaa käsittää enempää väärin.

Kaikki edellä mainittu kuitenkin vaikuttaa luottamushenkilöiden päätöksentekoon. Mikäli kirkossa tahdotaan tehdä vaikuttavaa diakoniatyötä, on välttämätöntä haastaa myös herätysliikkeitä ja kaikkia päättäjiä miettimään diakoniaa omassa toiminnassaan. 
Samankaltaiseen ajatteluun törmää ns. uskoon tuloa korostavan aikuistyön aktiivien parissa, vaikkei heillä herätysliiketaustaa olisikaan. Näyttää siltä, että seurakunnan ns. aikuistyön aktiiviväen ajattelu eroaa muusta seurakunnan jäsenistöstä. Päätöksentekijöiden strategiset valinnat ja niiden eriytymisen koko jäsenistön mielipiteistä on syytä huomioida, sillä vaikutukset kirkon jäsenyydelle ja diakoniaseurakunnalle ovat ilmeiset. Kohtalainen väite, jota olisi hyvä tutkia.

\section{Suljetun järjestelmän ongelma}

Päätöksissä on kyse myös siitä, keitä päätöksiä tehtäessä kuullaan, miten päätökset muodostuvat ja kuinka avoimesti päätösprosesseja voidaan jäljittää. Hyvänä esimerkkinä on kirkon tulevaisuusvaliokunnan viimeisin mietintö, jota käsiteltiin kirkolliskokouksessa elokuussa 2021. Mietintö pyrki nostamaan esiin muutostarpeita, joihin olisi reagoitava, jotta kirkko pysyisi merkityksellisenä jäsenilleen. Valitettavasti mietintö pohjautui pitkälti vanhaan tietoon ja ilmeisen vääriin mielikuviin diakoniasta. Päättäjien diakoniakäsityksestä kertoo jotain se, että tulevaisuusvaliokunnan mietinnöstä puuttuu täysin diakonian hengellinen ulottuvuus. Diakonia ei ole jotain, mikä on julistuksen rinnalla tai lisäksi. Diakoniassa toteutuu kirkon hengellinen tehtävä. Kirkossamme on käännetty peistä yli 50 vuotta diakonian viran asemasta. Diakonian virka tulisi yksiselitteisesti olla osa kolmisäikeistä virkaa.

Mietinnöstä käy ilmi, että valiokunta on kuullut useita kansanedustajia ja pappeja,järjestöjen työntekijöitä ja kasvatuksen asiantuntijoita. Lisäksi kuultavana on ollut yksi nuorisodiakoni ja yksi diakoniatyöntekijä. Mietintö on kaikkien arvioitavana. Sen sijaan valiokunnan ulkopuolelta meistä kukaan ei voi arvioida, mitä kutsutut asiantuntijat ovat esittäneet ja miten valiokunta on ottanut heidän näkemyksensä huomioon. Kirkon päätösten valmisteluprosessit on suljettu myös kirkon ylimmiltä päättäjiltä. Kirkolliskokousedustaja ei saa käyttöönsä valiokunnan kuulemien tahojen esityksiä ja onko niillä ollut lopputulokseen vaikutusta.

Avoimuutta tarvitaan päätöksentekoon liittyvien dokumenttien jakamisessa. Pääosin kirkollisten toimijoiden esityslistat ja pöytäkirjat ovat löydettävissä internetistä, mutta varsin yleistä on, että liiteaineistoja ei laiteta yleisön saataville, vaikka materiaaliin ei oletettavasti liity salassa pidettävää tietoa. Tällainen hidastaa tai estää kokonaan vuorovaikutuksen päättäjien ja seurakuntalaisten tai diakonian toimijoiden välillä. Nykykäytännön mukaiset sul- 
jetut järjestelmät eivät ole tätä päivää. Diakoniatyön vaikuttavuuden lisäämiseksi kirkollista päätöksenteon avoimuutta ja arvioitavuutta kasvattaisikin se, että eri valiokuntien tai valmisteluryhmien kuulemien asiantuntijoiden lausunnot olisivat kirjallisena ja kaikkien luettavissa ja arvioitavissa.

\section{Kohti osallistavaa päätöksentekoa}

Lisäksi kirkolliskokous voisi uudistaa toimintatapojaan siten, että valmistelussa olevista asioista on mahdollista lausua kaikilla halukkailla, samaan tapaan kuin valtionhallinnossa. Nykyisen kaltaiset tavat kerätä tietoa päätöksenteon tueksi ovat usein kustannustehottomia, hitaita, ulossulkevia ja saattavat helposti jäädä kapea-alaisiksi. Kirkollinen päätöksenteko tarvitsee uutta ajattelua, se ei voi marginalisoitua harvojen etuoikeudeksi. Valitettavasti nykyiset kirkon ja seurakuntien hallintomallit ja -tavat ovat osittain kankeita eivätkä edistä päätöksentekoprosessien muuttumista. Lisäksi taistelu vallasta ja kirkon sisäiset jakolinjat näyttäisivät jarruttavan tarpeellista uudistumista. Ei riitä, että päättäjille välitetään tietoa, jota matkalla suodatetaan toimikunnan, työryhmän tai esittelijän toimesta. Tällaisessa perinteisessä päätösprosessissa vuorovaikutus on ohutta tai liki olematonta.

Tulevaisuuden päätöksenteko täytyy rakentua osallistamiselle, jossa yhteisesti laajennetaan ymmärrystä käsillä olevasta asiasta, etsitään erilaisia tiedon tarjoajia ja ollaan aktiivisesti yhteydessä eri toimijoihin. Tähän tarvitaan toimintakulttuurin muutos. Päätöksentekoon liittyen diakoniatyöntekijöillä on liian monia kokemuksia ohittamisesta, sivuuttamisesta ja kuulluksi tulemattomuudesta. Diakoniatyöntekijöillä on halu osallistua yhteiseen asioiden pohtimiseen, valmisteluun ja päätöksentekoon. Rakennettaessa tulevaisuuden kirkkoa ei ole varaa olla ottamatta käyttöön tätä osaamista.

Helppo ja luonteva tapa lisätä päättäjien tuntemusta diakoniasta on ottaa diakoniatyöntekijät tai johtava diakonian viranhaltija mukaan seurakunta- tai kirkkoneuvostoon esittelemään omaan työalaansa liittyviä päätösasioita. Näin luodaan välitön yhteys paikallisesti heihin, jotka työtä tekevät ja päättäjät saavat käyttöönsä ajantasaisimman tietämyksen työalalta.

\section{Reflektion paikka}

Diakoniatyöntekijät tuntevat reflektion, jossa omaa asennetta, kokemuksia ja faktoja tarkastellaan kriittisesti etsien uudistavaa asennetta työhön. Myös dia- 
koniaviestintää on syytä reflektoida. Miten diakonian asiantuntijoina olemme onnistuneet kertomaan työstämme ja osaamisestamme? Olemmeko luovuttaneet liian helposti, jos viestimme ei mene eteenpäin? Kysymykset auttavat pohdinnassa, mutta sen jälkeen tarvitaan myös toimenpiteitä.

Kun diakonian asiantuntijana saa tilaisuuden kertoa työstään, on tilaisuus myös käytettävä. Ei pidä olettaa, että päättäjät tuntevat diakonian arkea. On perusteltava ja uskallettava taistella myös omien resurssien puolesta. Kirkossa on otettava paikkansa, tultava esiin ja kerrottava näkemyksensä. Ei ole helppoa muuttaa totuttua toimintakulttuuria, mutta jos haluamme kirkosta inhimillisen ja moniäänisen on siihen ryhdyttävä.

Vuonna 2022 on kulunut 150 vuotta ensimmäisestä suomalaisesta diakonian virkaan vihkimisestä. Matilda Hoffman vihittiin diakonissaksi syyskuun 1. päivä 1872 Pietari-Paavalin kirkossa Viipurissa. Juhlavuonna nostetaan esiin seurakuntien diakoniatyötä, ammatillista diakoniaa ja diakonian vihkimysvirkaa. Diakonian juhlavuosi antaa tähän sekä vuorovaikutukseen päättäjien kanssa luontevan mahdollisuuden. 